\title{
Microbial Degradation of a Recalcitrant Pesticide: Chlordecone
}

\section{OPEN ACCESS}

Edited by:

Fabrice Martin-Laurent,

INRA, France

Reviewed by:

Edoardo Puglisi,

Catholic University of the Sacred

Heart, Italy

Ines Sviličić Petrić,

Rudjer Boskovic Institute, Croatia

*Correspondence:

Denis Le Paslier

denis@genoscope.cns.fr

${ }^{\dagger}$ These authors have contributed equally to this work.

Specialty section:

This article was submitted to Systems Microbiology, a section of the journal

Frontiers in Microbiology

Received: 05 August 2016 Accepted: 02 December 2016 Published: 20 December 2016

Citation:

Chaussonnerie S, Saaidi P-L, Ugarte E, Barbance A, Fossey A,

Barbe V, Gyapay G, Brüls T, Chevallier M, Couturat L, Fouteau S,

Muselet D, Pateau E, Cohen GN,

Fonknechten N, Weissenbach J and

Le Paslier D (2016) Microbial

Degradation of a Recalcitrant

Pesticide: Chlordecone.

Front. Microbiol. 7:2025

doi: 10.3389/fmicb.2016.02025

\author{
Sébastien Chaussonnerie ${ }^{1,2,3 \dagger}$, Pierre-Loïc Saaidi 1, 2,3†, Edgardo Ugarte ${ }^{1,2,3 \dagger}$, \\ Agnès Barbance 1,2,3, Aurélie Fossey 1,2,3, Valérie Barbe ${ }^{1}$, Gabor Gyapay ${ }^{1}$, \\ Thomas Brüls ${ }^{1,2,3}$, Marion Chevallier ${ }^{1,2,3}$, Loïc Couturat 1, 2, 3, Stéphanie Fouteau ${ }^{1}$, \\ Delphine Muselet 1,2,3, Emilie Pateau 1,2,3, Georges N. Cohen ${ }^{4}$, Nuria Fonknechten 1,2,3, \\ Jean Weissenbach ${ }^{1,2,3}$ and Denis Le Paslier ${ }^{1,2,3 *}$ \\ ${ }^{1}$ Commissariat à l'Energie Atomique et aux Energies Alternatives, Direction de la Recherche Fondamentale, Institut de \\ Génomique, Evry, France, ${ }^{2}$ Université d'Evry Val d'Essonne, Evry, France, ${ }^{3}$ Centre National de la Recherche Scientifique, \\ UMR8030, Génomique métabolique, Evry, France, ${ }^{4}$ Institut Pasteur, Paris, France
}

Chlordecone (Kepone $\left.{ }^{\circledR}\right)$ is a synthetic organochlorine insecticide $\left(\mathrm{C}_{10} \mathrm{Cl}_{10} \mathrm{O}\right)$ used worldwide mostly during the 1970 and 1980s. Its intensive application in the French West Indies to control the banana black weevil Cosmopolites sordidus led to a massive environmental pollution. Persistence of chlordecone in soils and water for numerous decades even centuries causes global public health and socio-economic concerns. In order to investigate the biodegradability of chlordecone, microbial enrichment cultures from soils contaminated by chlordecone or other organochlorines and from sludge of a wastewater treatment plant have been conducted. Different experimental procedures including original microcosms were carried out anaerobically over long periods of time. GC-MS monitoring resulted in the detection of chlorinated derivatives in several cultures, consistent with chlordecone biotransformation. More interestingly, disappearance of chlordecone $(50 \mu \mathrm{g} / \mathrm{mL})$ in two bacterial consortia was concomitant with the accumulation of a major metabolite of formula $\mathrm{C}_{9} \mathrm{Cl}_{5} \mathrm{H}_{3}$ (named B1) as well as two minor metabolites $\mathrm{C}_{10} \mathrm{Cl}{ }_{9} \mathrm{HO}$ (named $\mathrm{A} 1$ ) and $\mathrm{C}_{9} \mathrm{Cl}_{4} \mathrm{H}_{4}$ (named B3). Finally, we report the isolation and the complete genomic sequences of two new Citrobacter isolates, closely related to Citrobacter amalonaticus, and that were capable of reproducing chlordecone transformation. Further characterization of these Citrobacter strains should yield deeper insights into the mechanisms involved in this transformation process.

Keywords: anaerobic biodegradation, chlordecone, Citrobacter, kepone, organochlorine, pesticides, analytical chemistry, metagenomics

\section{INTRODUCTION}

Chlordecone (Kepone ${ }^{\circledR}, \mathrm{C}_{10} \mathrm{Cl}_{10} \mathrm{O}$ ) is an organochlorine pesticide formerly used worldwide (Europe, USA, Latin America, Africa as well as in Asia) (UNEP/POPS/POPRC.3/10, 2007; Fritz, 2009; Le Déault and Procaccia, 2009; Joly, 2010). Its rare perchlorinated bishomocubane structure, present in only two other insecticides, Kelevan and Mirex (used also as fire-retardant), originates from the dimerization of hexachlorocyclopentadiene which is a key intermediate in the synthesis of many other organochlorine pesticides (e.g., aldrin, dieldrin, heptachlor, or endosulfan) (Matolcsy et al., 1988). Mirex $\left(\mathrm{C}_{12} \mathrm{Cl}_{12}\right)$ differs from chlordecone, as it possesses a dichloromethylene group in place of carbonyl moiety. Kelevan $\left(\mathrm{C}_{17} \mathrm{H}_{12} \mathrm{Cl}_{10} \mathrm{O}_{4}\right)$ used in Europe to fight against the Colorado 
potato beetle is made from chlordecone by addition of ethyl levulinate onto the ketone function (Gilbert et al., 1966). Both compounds are known to generate chlordecone among other degradative metabolites in environmental conditions (Le Déault and Procaccia, 2009).

Chlordecone was intensively applied in the French West Indies for the control of the banana root borer (19721978; 1981-1993) despite hints of high toxicity reported in a number of animal species (Epstein, 1978). In humans, recent epidemiological and toxicological studies have demonstrated that chlordecone is a reproductive and developmental toxicant, an endocrine-disrupting chemical and a neurotoxic. It is also consistently associated with an increase in the risk of prostate cancer (Multigner et al., 2010, 2016; Cordier et al., 2015; Emeville et al., 2015). Chlordecone persists in the environment (Cabidoche et al., 2009; Fernández-Bayo et al., 2013; Devault et al., 2016), and since it bioaccumulates as it moves through the food chain, it was listed in the Persistent Organic Pollutants (POPs) prohibition list of the Stockholm Convention (UNEP/POPS/POPRC.1/INF/6, 2005).

In human and some mammals, chlordecone is metabolized in liver: after reduction into chlordecol, a chlordecol-glucuronide is formed and excreted (Fariss et al., 1980; Houston et al., 1981; Soine et al., 1983; Figure 1A). Only a few studies have reported on microbial transformation of chlordecone. In two cases the observed metabolites were limited to mono- and dihydro-chlordecone derivatives with only weak disappearance of chlordecone (Orndorff and Colwell, 1980; George and Claxton, 1988; Figure 1B). Using ${ }^{14} \mathrm{C}$-chlordecone, Jablonski et al. could detect polar and apolar metabolites, but no additional characterizations were carried out in order to elucidate their structure (Jablonski et al., 1996). Chlorinated derivatives could also arise from commercial chlordecone preparations as exemplified in several studies (Cabidoche et al., 2009; Fernández-Bayo et al., 2013; Merlin et al., 2014) (Supplementary Figure 1). More recently, traces of biomineralization activity coupled with chlordecone decrease were reported independently in aerobic soil microcosms (Fernández-Bayo et al., 2013) and in a fungal population (Merlin et al., 2014), however in neither cases could be detected significant amount of metabolites accounting for putative chlordecone degradation. Instead, Merlin et al. showed a strong sorption of ${ }^{14} \mathrm{C}$ chlordecone onto fungal biomass (Merlin et al., 2014). As for the metabolites detected so far, very little has been reported on the microbial species mentioned in the previous studies. Given its chemical structure, we hypothesized that chlordecone is more likely to serve as an electron acceptor in the initial degradation steps (Dolfing et al., 2012) than to undergo any other transformation. This initial phase should happen under anaerobic conditions where most highly chlorinated compounds are biotransformed (Hug et al., 2013). Such an assumption is also supported by the known reactivity of chlordecone in presence of chemical reducing agents. Application of zerovalent iron to chlordecone contaminated soils led to the detection of mono- and poly-hydrochlordecone derivatives $\left(\mathrm{C}_{10} \mathrm{Cl}_{10-n} \mathrm{H}_{\mathrm{n}}, 1 \leq \mathrm{n} \leq 5\right)$ (Mouvet et al., 2016; Figure 1C) while vitamin $\mathrm{B}_{12 s}$ (reduced form) induced conversion of chlordecone into both hydrochlordecone derivatives and apolar $\mathrm{C}_{9}$-compounds $\left(\mathrm{C}_{9} \mathrm{Cl}_{6-\mathrm{n}} \mathrm{H}_{2+\mathrm{n}}, 1 \leq \mathrm{n} \leq 3\right)$ presumably assigned as polychloroindenes (Schrauzer and Katz, 1978; Figure 1D). In comparison, photolytic degradation of chlordecone gave rise only to 5b-monohydrochlordecone and 5b,-6-dihydrochlordecone (Wilson and Zehr, 1979; Figure 1E).

The purpose of the present work was thus to fully characterize microflora able to transform chlordecone, clearly identify its metabolites and determine whether their gene content could explain the chlordecone degradation mechanisms. To achieve this goal, three experimental strategies were explored: direct soils cultures, bacteria extracted from soils/sludges cultures and bacteria extracted from soils/sludges on microcosms. Bacterial samples used for these enrichments came from organochlorines contaminated soils and sediments, as well as from two basins of a wastewater treatment plant (Evry, France). After 1 year several chlordecone metabolites were detected as traces by GC-MS in some cultures from microcosm enrichments. Two consortia (86 and 82) from subsequent enrichments were able to open the perchlorinated bishomocubane structure of chlordecone, resulting in a $\mathrm{C}_{9}$-compound $\mathrm{B} 1\left(\mathrm{C}_{9} \mathrm{Cl}_{5} \mathrm{H}_{3}\right)$. Similar metabolites were previously obtained by chemical degradation of chlordecone with vitamin $\mathrm{B}_{12 \mathrm{~s}}$ (Schrauzer and Katz, 1978), via removal of five chlorine as well as one carbon and one oxygen atoms. Subsequently, two Citrobacter species were isolated from these consortia and showed the same degradative capacity against chlordecone.

\section{MATERIALS AND METHODS}

\section{Soils, Sediments, and Sludge Samples: Sources of Microorganisms}

Three soil types on which bananas were grown were collected in Guadeloupe in April 2010 and their chlordecone concentration was estimated: Andosol (a, $30 \mathrm{mg}$ chlordecone/kg Dry Soil, DS), Fluvisol (b, $60 \mu \mathrm{g}$ chlordecone/kgDS) and Nitisol (c, $1.5 \mathrm{mg}$ chlordecone/kgDS) by Cabidoche Y.M. (personal communication).

In addition, organochlorines contaminated soils and sediments (dichloropropane, Bis(2-chloroisopropyl) ether (d); tetrachloroethylene and trichloroethylene (e) were used as well as sludge samples from the aerobic (f) or anoxic (g) basins of the wastewater treatment plant (WWTP) of Evry (Chouari et al., 2003).

\section{Experimental Strategies and Enrichment Conditions}

The mineral medium (MM) used was as described (Löffler et al., 1996) with the following modification: $\mathrm{KH}_{2} \mathrm{PO}_{4}$ was replaced by a $10 \mathrm{mM}\left(\mathrm{KH}_{2} \mathrm{PO}_{4}\right.$ and $\left.\mathrm{K}_{2} \mathrm{HPO}_{4}\right)$ phosphate buffer, $\mathrm{pH}$ 7.5. When indicated this medium was supplemented with 10 $\mathrm{mM}$ pyruvate as carbon source, $2 \mathrm{~g} / \mathrm{L}$ yeast extract and $2 \mathrm{~g} / \mathrm{L}$ tryptone $(\mathrm{MM}+) .0 .4 \mathrm{~g} / \mathrm{L} \mathrm{Na} \mathrm{N}_{2} \mathrm{~S}, 0.05 \mathrm{~g} / \mathrm{L}$ cysteine- $\mathrm{HCl}, 0.5 \mathrm{mM}$ dithiothreitol (DTT) were used as reductants and $0.1 \%$ resazurin as an indicator of anaerobiosis. 


\section{A Metabolism in human and several mammals}

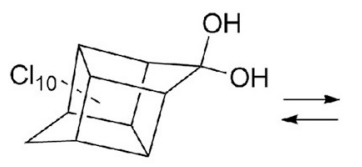

chlordecone

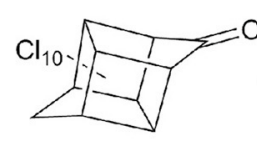

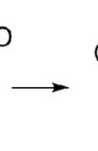

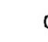

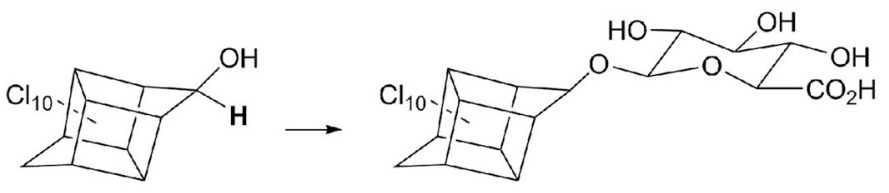

chlordecol-glucuronide

B Bacterial degradation

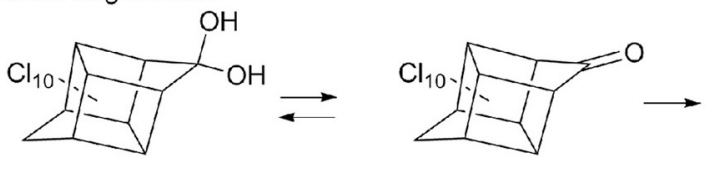

chlordecone

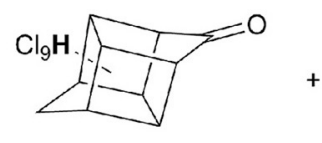

monohydrochlordecone

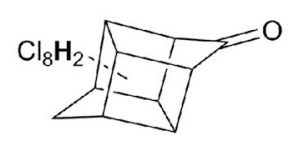

dihydrochlordecone

C Zero-valent iron degradation

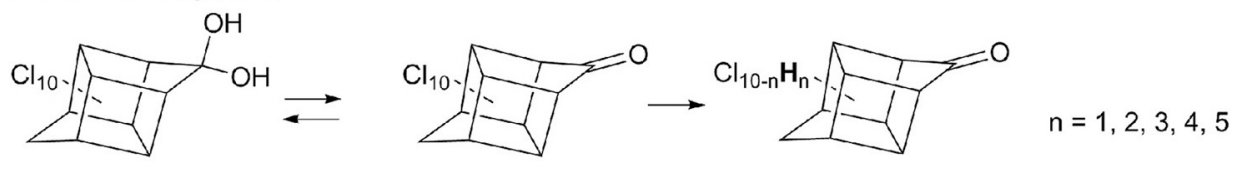

chlordecone

hydrochlordecones

D Vitamin $B_{12 s}$ reductive degradation

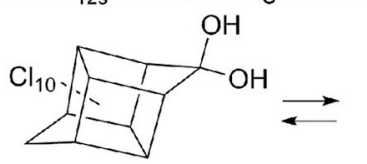

chlordecone

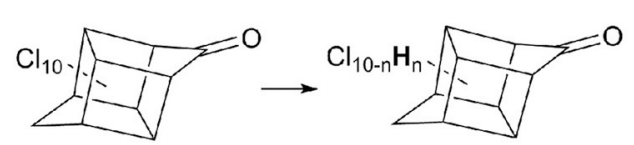

hydrochlordecones<smiles></smiles>

$n=1,2,3,4$

$m=1,2,3$ polychloroindenes (postulated)

\section{E Photolytic degradation}

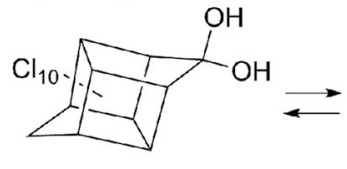

chlordecone

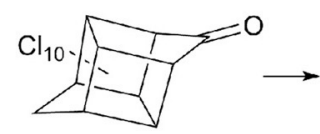

5b-monohydrochlordecone

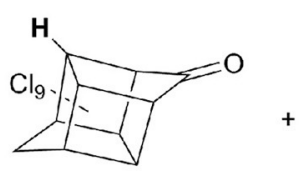

5b,6-dihydrochlordecone

FIGURE 1 | Summary of known metabolic and degradative pathways for chlordecone: (A) human and mammals metabolism (Fariss et al., 1980; Houston et al., 1981; Soine et al., 1983), (B) aerobic and anaerobic bacterial degradation (Orndorff and Colwell, 1980; George and Claxton, 1988), (C) zero-valent iron degradation (Mouvet et al., 2016), (D) vitamin B 12s $_{\text {s }}$ reductive degradation (Schrauzer and Katz, 1978), (E) photolytic known degradation (Wilson and Zehr, 1979). For clarity, hydrated ketone moiety was only represented for chlordecone, even if it presumably occurs for all hydrochlordecones.

Liquid cultures in $\mathrm{MM}$ or $\mathrm{MM}+$ medium were carried out in $100 \mathrm{~mL}$ glass serum vials, sealed with butyl rubber septa and incubated in room temperature.

Analytical standard chlordecone (Ehrenstorfer GmbH, Fluka 45379, Pestanal ${ }^{\circledR}$ and Supelco 49046) was solubilized in dimethylformamide (DMF) to a $200 \mathrm{mg} / \mathrm{mL}$ stock solution.

Enrichment cultures were conducted following the three strategies described below (Supplementary Figure 2).

\section{Strategy 1: Soil Cultures}

Soils (, , b and c) and sediments samples (d and e) were anaerobically transferred to $50 \mathrm{~mL} \mathrm{MM}$ medium following these conditions: 5 or $10 \mathrm{~g}$ of samples as inoculum, MM supplemented or not with yeast extract (5 g/L), chlordecone (final concentrations of 2, 1 or $0.2 \mathrm{mg} / \mathrm{mL}$ ). Culture vials were incubated under $\mathrm{N}_{2}, \mathrm{H}_{2}, \mathrm{CO}_{2}(90,5,5 \%)$ atmosphere. During the incubation for $\sim 6$ months, subculturing by a $10 \%$ transfer to fresh media was carried out once 2 weeks.

\section{Strategy 2: Nycodenz ${ }^{\circledR}$ Cultures}

Bacterial fractions from $60 \mathrm{~g}$ of soil ( $\mathrm{a}$ and $\mathrm{b}$ ), and of $60 \mathrm{~g}$ sediments samples ( $d$ and e) were collected via a Nycodenz ${ }^{\circledR}$ gradient (Bertrand et al., 2005) and resuspended in $2 \mathrm{~mL}$ $\mathrm{NaCl} 0.8 \%$.

$20 \mathrm{~mL}$ MM medium cultures were established using 2, 1 or $0.5 \mathrm{ml}$ of bacterial fraction as inoculum, MM supplemented or 
not with yeast extract $(5 \mathrm{~g} / \mathrm{L})$, chlordecone (final concentrations of 2,1 , or, $0.2 \mathrm{mg} / \mathrm{mL}$ ). Culture vials were incubated under $\mathrm{N}_{2}$, $\mathrm{H}_{2}, \mathrm{CO}_{2}(90,5,5 \%)$ atmosphere. $10 \%$ of the enrichment cultures were transferred to fresh media $(50 \mathrm{~mL})$ once 2 weeks.

\section{Strategy 3: Microcosms}

Microcosms were prepared with $250 \mathrm{~g}$ of sieved and autoclaved soil from the Genoscope premises ( $48^{\circ} 37^{\prime} 22.76^{\prime \prime} \mathrm{N} ; 2^{\circ} 26^{\prime} 20.61^{\prime \prime}$

E). Control microcosms M1 and M2 were inoculated with G1505 Escherichia coli strain (Bouzon-Bloch, unpublished). Microcosms M3 to M6 were inoculated with the purified bacterial fraction obtained after Nycodenz ${ }^{\circledR}$ gradients: M3 was from the aerobic basin (f), M4 was from anoxic basin (g), M5 and M6 were from fluvisol (b). Microcosms were perfused during 1 year with mineral medium (MM) containing $2 \mathrm{mg} / \mathrm{mL}$ chlordecone. Excess liquid medium was recovered and used again for perfusion or a new medium was added when the microcosm soils became dry. After 1 year, excess liquid from microcosms was used to inoculate liquid bacterial cultures. $50 \mathrm{~mL}$ MM medium were inoculated with a $10 \%$ dilution of each of the 6 perfused samples in presence of chlordecone (final concentrations 2, 1, 0.2, or $0.05 \mathrm{mg} / \mathrm{mL}$ ) and under $\mathrm{N}_{2}, \mathrm{H}_{2}(95,5 \%)$ atmosphere. During the incubation period ( $\sim 1$ year), subculturing by a $10 \%$ transfer to fresh MM was carried out monthly in case of growth, monitored by microscopic observations. Enrichments were also performed on a pool of the 6 liquid cultures (coming from M1 to M6). Sample without inoculum was used as control.

Enrichment cultures were then plated on 2\% agar $(\mathrm{MM}+$, $50 \mu \mathrm{g} / \mathrm{mL}$ chlordecone). Subsequently, picked colonies were grown in liquid $\mathrm{MM}+(50 \mu \mathrm{g} / \mathrm{mL}$ chlordecone $)$.

\section{Bacteria Isolation from Consortia 86 and 92 (Supplementary Figure 2)}

Four successive extinction dilution liquid cultures experiments were carried out $\left(\mathrm{v} / \mathrm{v}, 10^{-2}-10^{-11}\right)$ on $\mathrm{MM}+(50 \mu \mathrm{g} / \mathrm{mL}$ chlordecone) under $\mathrm{H}_{2}, \mathrm{~N}_{2}(5,95 \%)$ atmosphere. Last dilution growing cultures were spread on $2 \%$ agar plates $(\mathrm{MM}+$, $50 \mu \mathrm{g} / \mathrm{mL}$ chlordecone) and isolated colonies were purified three times in the same medium.

\section{S rRNA Gene Analysis}

$16 \mathrm{~S}$ rRNA gene amplification and sequence analyses were performed as described (Riviere et al., 2009).

\section{Metagenomic Sequencing of Bacterial Consortia 86 and 92}

Genomic DNA was extracted from $50 \mathrm{~mL}$ cultures from the two bacterial consortia 86 and 92 (Bertrand et al., 2005). Sequencing of the two consortia 86 and 92 was performed on Illumina instruments (http://www.illumina.com). Genomic DNA of these metagenomes was extracted and fragmented according to the targeted library fragment size. Inserts from 150 to $300 \mathrm{bp}$ and from 8 to $10 \mathrm{~kb}$ were selected to construct paired-end (PE) and mate-pair (MP) libraries respectively. These libraries were loaded on HiSeq2500 sequencing device flowcells (150 nt were sequenced at each extremity) producing 6-10 Gb (PE data) and $23 \mathrm{~Gb}$ (MP data). The PE reads of a same fragment were merged (leading to $\sim 180 \mathrm{nt}$ read length on average), assembled with Newbler (http://www.roche.com) and contigs larger than $2 \mathrm{~kb}$ were ordered by SSPACE (Boetzer et al., 2011). Based on SSPACE output files, we constructed 10 and 7 scaffold pools for consortia 86 and 92 respectively, most of them corresponding to almost complete genome (Table 1). Paired-end and mate-pair data were then individually mapped with BWA (Burrows-Wheeler Aligner, http://bio-bwa.sourceforge.net) on each pool resulting on batch reads that were assembled using a mix of Newbler/SSpace or only Newbler. GapCloser (http://soap.genomics.org.cn/soapdenovo. html) was run successively with the PE and MP data to reduce the number of undetermined bases (Supplementary Table 1). Completeness and representativeness of the assembly was assessed using sequence clustering (binning) software described in Gkanogiannis et al. (2016). The assembly data were integrated for automatic annotation into the Microscope platform (Vallenet et al., 2013), http://www.genoscope.cns.fr/agc/microscope/home. This platform has been used for subsequent manual annotation. Accessions numbers are available in supplementary material.

\section{Genomic Sequencing of the Isolated Citrobacter Strains}

Genomic DNA was extracted from $50 \mathrm{~mL}$ cultures of the two isolated Citrobacter 86-1 and Citrobacter 92-1 as described (Bertrand et al., 2005). Sequencing was performed on Illumina instruments. For both genomes, an overlapping paired-end and a $8 \mathrm{~kb}$ mate-pair libraries were constructed out and loaded on MiSeq $(2 \times 300 \mathrm{nt})$ and HiSeq2500 $(2 \times 150 \mathrm{nt})$ sequencing device flowcells respectively. The PE (corresponding to 38 fold coverage for Citrobacter 86-1 and 25 fold coverage for Citrobacter 92-1) and MP (corresponding to 50 fold coverage for Citrobacter 86-1, 42-fold coverage for Citrobacter 92-1) data were assembled with Newbler. To validate the Citrobacter_86-1 and Citrobacter 92-1 genome assemblies, optical maps were obtained from the Argus Whole-Genome Mapping System (www.opgen.com) for both genomes. The average size of the single-molecule restriction maps was $270 \mathrm{~kb}$ and $230 \mathrm{~kb}$ for Citrobacter $86-1$ and Citrobacter 92-1 respectively. For each genome, we obtained one assembly map with a total size of $\sim 4.9 \mathrm{Mb}$. No misassembly was detected after analysis but variations (essentially due to displacement of insertion sequences) were observed between Citrobacter_86-1 and Citrobacter_92-1 genomes (Supplementary Figure 3). Accessions numbers are available in supplementary material.

\section{Organochlorines Extraction for Microbiological Culture Monitoring}

Samples were usually extracted from cultures twice a month. After homogenization of the liquid culture, $500 \mu \mathrm{L}$ of the turbid solution were collected and extracted twice using $250 \mu \mathrm{L}$ isooctane.

\section{GC-MS Samples}

Three $\mu \mathrm{L}$ of the combined organic layers were injected in splitless mode into the GC-MS. 


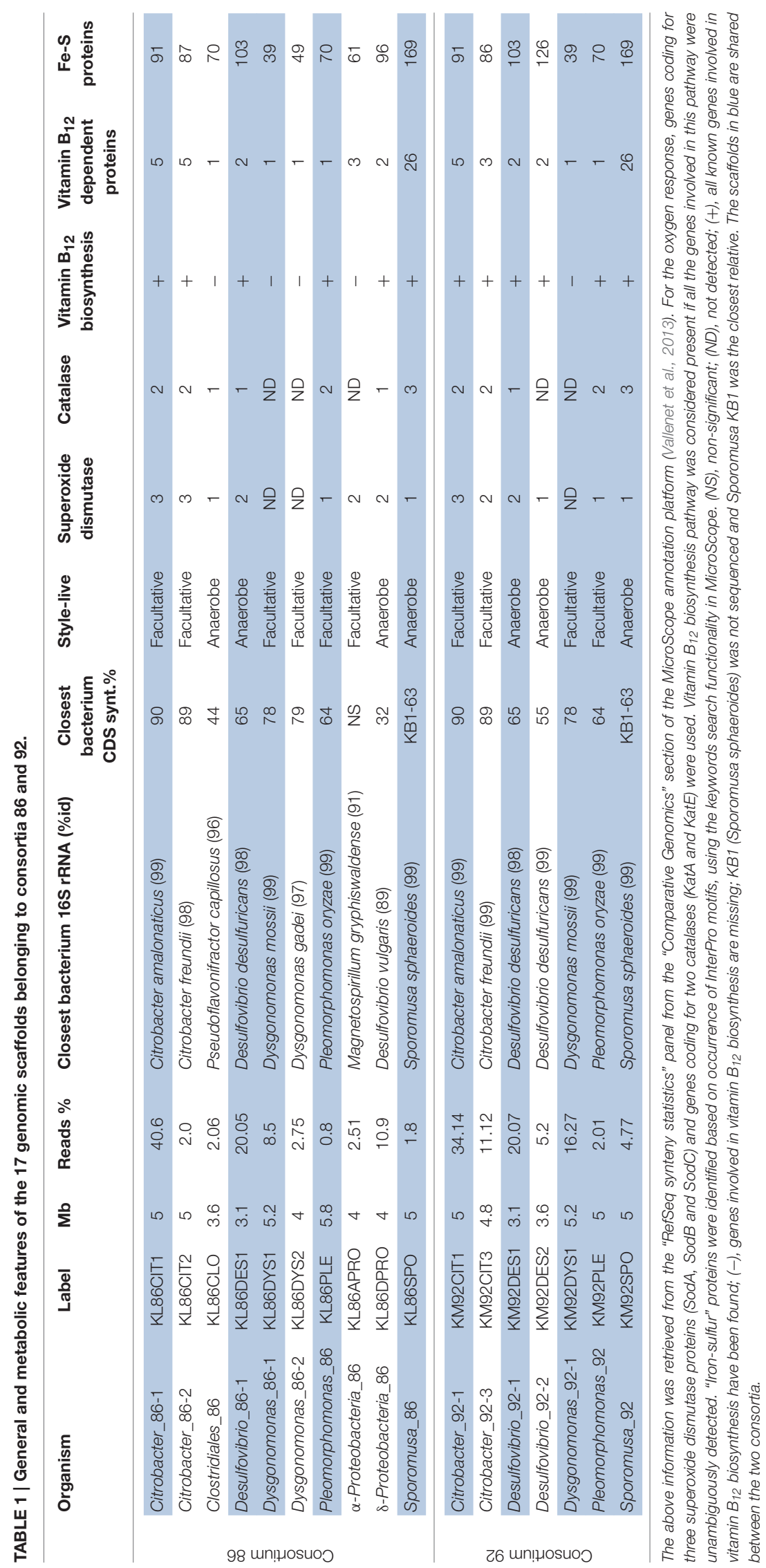




\section{LC-MS Samples}

The combined organic layers were air-dried, solubilized in $500 \mu \mathrm{L}$ acetonitrile, diluted with mobile phase (v/v, 1/4) and filtered. Three micro litter of the resulting solution were injected.

\section{Gas Chromatography Coupled to Mass Spectrometry Analysis (GC-MS) for Microbiological Culture Monitoring}

GC-MS analysis was performed on a gas chromatograph (GC), (Thermo Fisher Focus GC) coupled to a single-quadrupole mass spectrometer (Thermo Fisher DSQ II). The instrument was equipped with a non-polar $30 \mathrm{~m} \times 0.25 \mathrm{~mm} \times 0.25 \mu \mathrm{m}$ DB-5MS column (Agilent J\&W) and a split/splitless injector. Carrier gas was helium at a constant flow rate of $1 \mathrm{~mL} \mathrm{~min}^{-1}$. GC program started at $80^{\circ} \mathrm{C}$ (hold time $1 \mathrm{~min}$ ), continued with $50^{\circ} \mathrm{C} \mathrm{m^{-1 }}$ to $140^{\circ} \mathrm{C}$, followed by $6^{\circ} \mathrm{C} \mathrm{min}^{-1}$ to $280^{\circ} \mathrm{C}$ (hold time $5 \mathrm{~min}$ ). Injection and transfer line temperatures were set up at $200^{\circ} \mathrm{C}$, respectively $280^{\circ} \mathrm{C}$. For mass spectrometry (MS) analyses, the following standard working conditions were applied: electronic impact ionization, positive mode detection, ion source at $220^{\circ} \mathrm{C}$, detector voltage $70 \mathrm{eV}$, full scan mode $\mathrm{m} / \mathrm{z}$ 50-650 (scan time 0.26 $\mathrm{sec})$.

\section{Liquid Chromatography Coupled to High Resolution Mass Spectrometry Analysis (LC-MS) for Exact Mass Determination of Metabolites A1, B1, and B3}

Analyses were conducted using a Dionex Ultimate 3000 LC system (Thermo Fisher Scientific) coupled to a LTQ-OrbiElite mass spectrometer (Thermo Fisher Scientific) fitted with a heated electrospray ionization source (HESI) operating in negative ionization mode. Mass spectra were acquired over an $\mathrm{m} / \mathrm{z}$ range from $\mathrm{m} / \mathrm{z} 50$ up to $\mathrm{m} / \mathrm{z} 2000$ with the mass resolution set to 30.000 FWHM at $\mathrm{m} / \mathrm{z} 400$ in the Orbitrap analyzer.

For metabolite A1 and chlordecone, the ion spray voltage was set to $4.5 \mathrm{kV}$, the sLens RF level to $67.9 \%$, the heater temperature to $50^{\circ} \mathrm{C}$ and the capillary temperature to $275^{\circ} \mathrm{C}$. The sheath and auxiliary gas flows (both nitrogen) were respectively optimized at 60 and 50 (arbitrary units), and the sweep gas was set to 0 (arbitrary unit).

For metabolites B1 and B3, the ion spray voltage was set to 4.5 $\mathrm{kV}$, the sLens RF level to $60 \%$, the heater temperature to $275^{\circ} \mathrm{C}$ and the capillary temperature to $275^{\circ} \mathrm{C}$. The sheath and auxiliary gas flows (both nitrogen) were respectively optimized at 60 and 50 (arbitrary units), and the sweep gas was set to 0 (arbitrary unit).

The chromatographic separation was performed using an Acquity ${ }^{\circledR}$ C18 column (150 x $2.1 \mathrm{~mm} 2 ; 1.7 \mu \mathrm{m}$; Waters) and carried out at $40^{\circ} \mathrm{C}$ as follow: a mobile phase gradient was used with a flow rate of $0.3 \mathrm{~mL} \mathrm{~min}{ }^{-1}$ in which mobile phase A consisted of $10 \mathrm{mM}$ ammonium carbonate with $\mathrm{pH}$ adjusted to 9 and mobile phase B consisted of acetonitrile. The gradient started at $60 \%$ A for $2 \mathrm{~min}$, followed by a linear gradient at $100 \% \mathrm{~B}$ for $18 \mathrm{~min}$, and remained $10 \mathrm{~min}$ at $100 \% \mathrm{~B}$. The system returned to the initial solvent composition in $5 \mathrm{~min}$ and was re-equilibrated under these conditions for $15 \mathrm{~min}$.

\section{RESULTS AND DISCUSSION}

\section{Isolation of Bacteria That Degrade Chlordecone}

We initiated a large number of enrichment cultures (in MM medium supplemented with different chlordecone concentrations) under anaerobic conditions using as inoculum different soils or sediments contaminated with chlordecone or organochlorines (Supplementary Figure 2, Strategy 1). In addition, extracted bacterial fractions using a Nycodenz gradient separation method were used as inoculum (Supplementary Figure 2, Strategy 2). Most of these cultures did not grow and never produce detectable chlordecone metabolites (data not shown).

In parallel, six microcosms were established anaerobically with microorganisms of diverse origins and perfused with a mineral medium containing $2 \mathrm{mg} / \mathrm{mL}$ chlordecone (Supplementary Figure 2, Strategy 3). After 1 year of incubation, sediment-free liquid cultures were set up with the perfusing suspensions and renewed once a month by dilution (1/10, $\mathrm{v} / \mathrm{v})$ using fresh mineral medium (MM) containing decreasing chlordecone concentrations (from $2 \mathrm{mg} / \mathrm{mL}$ to $50 \mu \mathrm{g} / \mathrm{mL}$ ).

Cultures were regularly monitored by (i) microscopic observations showing slow growth and microbial diversity, (ii) GC-MS analysis allowing the detection of more than 40 chlorinated metabolites as trace compounds (Figure 2 and Table 2). Chlordecone metabolites (exempt 5bmonohydrochlordecone present as contaminant in CLD commercial preparations) were never detected by GC-MS analyses of control cultures.

After 1 year cultivation of these bacterial consortia, we attempted to isolate individual consortium members on agar

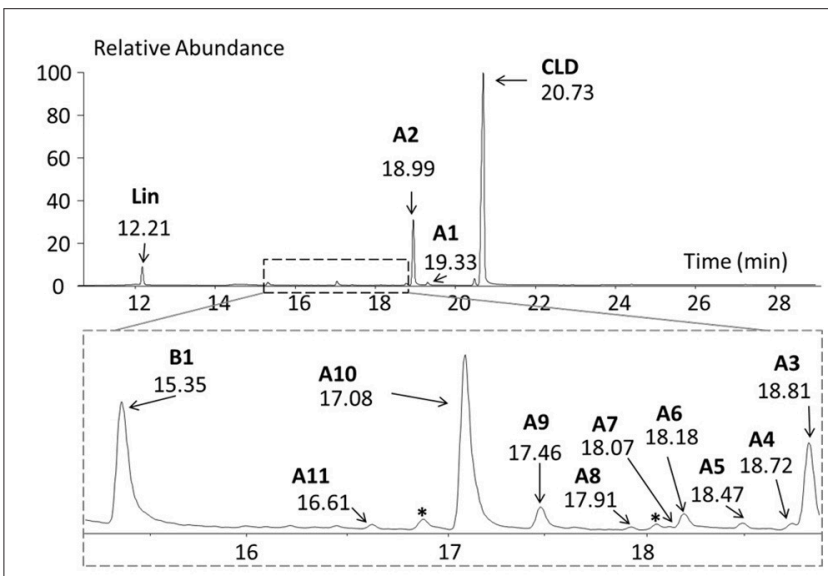

FIGURE 2 | GC-MS full scan chromatogram of a 700 days microbial culture. Metabolites A1, A2, A3, A4, A5, A6, A7, A8, A9, A10, A11, and B1 were detected (Table 2). *, other chlorinated compounds; Lin, lindane was used as an external extraction tracer. 
TABLE 2 | Metabolites library based on MS interpretation (Uk et al., 1972; Alley et al., 1974; Harless et al., 1978).

\begin{tabular}{lcl}
\hline Metabolites & Retention time (min.) & Postulated structure/formula \\
\hline A1 & $\mathbf{1 9 . 3}$ & monohydro-CLD \\
A2 & 19.0 & 5b-monohydro-CLD \\
A3 & 18.8 & mono or dihydro-CLD \\
A4 & 18.7 & mono or dihydro-CLD \\
A5 & 18.5 & mono or dihydro-CLD \\
A6 & 18.2 & dihydro-CLD \\
A7 & 18.1 & mono- or dihydro-CLD \\
A8 & 17.9 & mono- or dihydro-CLD \\
A9 & 17.5 & dihydro-CLD \\
A10 & 17.1 & dihydro-CLD \\
A11 & 16.6 & di- or trihydro-CLD \\
B1 & $\mathbf{1 5 . 4}$ & $\mathbf{C}_{\mathbf{9}} \mathrm{Cl}_{\mathbf{5}} \mathbf{H}_{\mathbf{3}}$ \\
B2 & 12.9 & $\mathrm{C}_{\mathbf{9}} \mathrm{Cl}_{4} \mathrm{H}_{4}$ \\
B3 & $\mathbf{1 1 . 7}$ & $\mathbf{C}_{\mathbf{9}} \mathrm{Cl}_{\mathbf{4}} \mathbf{H}_{\mathbf{4}}$ \\
\hline
\end{tabular}

Metabolites in bold refer to the main metabolites seen in Figure 4.

plates on a $\mathrm{MM}^{+}$medium containing $50 \mu \mathrm{g} / \mathrm{mL}$ chlordecone. 250 colonies were picked and analyzed through their $16 \mathrm{~S}$ rRNA gene sequences. Twenty colonies representative of the taxonomic diversity were grown further in liquid $\mathrm{MM}^{+}$medium (with 50 $\mu \mathrm{g} / \mathrm{mL}$ chlordecone). Growth was observed for seven colonies only, among which five selectively accumulated metabolite B1 $\left(\mathrm{C}_{9} \mathrm{Cl}_{5} \mathrm{H}_{3}\right)$ (Figure 3B). The two most active colonies were selected on the basis of chlordecone degradation, followed by GC-MS. 16S rRNA gene sequences analysis showed that these colonies were bacterial consortia and not pure cultures (hereafter called consortium 86 and consortium 92). Consortium 86 was obtained from the pool of the six microcosms (M1 to M6). Consortium 92 was obtained from microcosm M3 (aerobic basin of the WWTP of Evry). Since soil autoclaving does not ensure sterility, the exact origin of these colonies remains unknown. DNAs extracted from these two consortia were sequenced. Analyses of their metagenomes showed the presence of a dozen of bacterial organisms, five of which being shared between the two consortia (Table 1). To highlight bacteria or bacterium responsible of chlordecone transformation serial dilutions experiments were performed. Thus, consortia cultures were diluted until extinction and ability to produce metabolite $\mathrm{B} 1\left(\mathrm{C}_{9} \mathrm{Cl}_{5} \mathrm{H}_{3}\right)$ was checked for each dilution where growth was observed. The most diluted (between $10^{-6}$ and $10^{-8}$ ) sample producing $\mathrm{B} 1\left(\mathrm{C}_{9} \mathrm{Cl}_{5} \mathrm{H}_{3}\right)$ was used to inoculate the next dilution experiment. After four successive rounds of serial dilutions only one bacterial morphology was detected and these cultures were plated. Optical mapping and genome sequencing confirmed that colonies were two pure and very similar Citrobacter strains and correspond to Citrobacter_86-1 and Citrobacter_921 (Table 1). These two Citrobacter strains showed accumulation of an apparent major metabolite $\mathrm{B} 1\left(\mathrm{C}_{9} \mathrm{Cl}_{5} \mathrm{H}_{3}\right)$ concomitant to chlordecone decrease while minor metabolites $\mathrm{A} 1\left(\mathrm{C}_{10} \mathrm{Cl}_{9} \mathrm{HO}\right)$ and $\mathrm{B} 3\left(\mathrm{C}_{9} \mathrm{Cl}_{4} \mathrm{H}_{4}\right)$ were also formed (Figures 3, 4). Metabolite B1 usually becomes detectable 7-20 days after inoculation. It is worth noticing that, beyond the strict requirement of anaerobic conditions, chlordecone degradation strikingly occurs during the lysis phase, not in the exponential growth phase as one could have expected. This behavior is reminiscent of older observations about the dechlorination of hexachlorocyclohexane $(\mathrm{HCH})$ isomers by Citrobacter freundii (Jagnow et al., 1977). The authors showed indeed that dechlorination of $\gamma-\mathrm{HCH}$ may not be related to Citrobacter freundii growth since release of ${ }^{36} \mathrm{Cl}$ was maximal after a 3 days period of incubation in a complex medium. Therefore, one would hypothesize that dechlorination of chlordecone and $\gamma-\mathrm{HCH}$ are not related to halorespiration.

\section{Analyses of Chlordecone Metabolites}

The high chlordecone concentrations (from $2 \mathrm{mg} / \mathrm{mL}$ to 50 $\mu \mathrm{g} / \mathrm{mL}$ ) prevented quantitative measurements of chlordecone consumption, forcing us to mainly focus on the detection of its potential metabolites. The anticipated high number of samples (roughly thousand per year) to be analyzed guided us to a simplified qualitative analytical procedure. LC-MS technique was discarded due to solubility limitation caused by aqueous mobile phase and low MS-response for apolar chlorinated species. A liquid-liquid micro-extraction with pure isooctane followed by direct GC-MS analysis in full scan mode was developed. Contrary to polar organic solvents previously used for chlordecone extraction (Bristeau et al., 2014; Martin-Laurent et al., 2014), isooctane avoided the insertion of additional step (eg. solid phase extraction or solvent switch) prior to GC-MS analysis. Both electronic impact and chemical ionizations have been previously used to detect chlordecone and its two known metabolites (Harless et al., 1978). Since chemical ionization gave rise to broader chromatographic peaks, electronic impact ionization was finally retained. Even if a majority of microbiological experiments did not lead to any new chlorinated compounds, the fast analytical procedure appeared to be successful in a number of cases. Based on the analysis of several thousands of samples, a library associating MS data and retention time (RT) for more than 40 chlorinated metabolites has been established over the years.

MS data were interpreted using the extensive fragmentation work previously published for polychlorinated bishomocubanes including mirex, chlordecone and its two known partially dechlorinated derivatives (Uk et al., 1972; Alley et al., 1974; Harless et al., 1978). Finally, a chemical formula was postulated for 14 metabolites divided into two families: $\mathrm{C}_{10}$-compounds $\mathrm{Ai}(1 \leq \mathrm{i} \leq 11)$ and $\mathrm{C}_{9}$-compounds $\mathrm{Bi}(1 \leq \mathrm{i} \leq 3)$ (Figure 3 and Table 2). Compared to chlordecone fragments, mass spectra of metabolites Ai $(1 \leq \mathrm{i} \leq 11)$ showed similar isotopic patterns with one or two $\mathrm{Cl}$ atoms being replaced by $\mathrm{H}$ atoms: (i) fragments of generic formula $\mathrm{C}_{10} \mathrm{Cl}_{10-n} \mathrm{H}_{\mathrm{n}} \mathrm{O}^{+}$, $\mathrm{C}_{10} \mathrm{Cl}_{9-\mathrm{n}} \mathrm{H}_{\mathrm{n}} \mathrm{O}^{+}, \mathrm{C}_{10} \mathrm{Cl}_{8-\mathrm{n}} \mathrm{H}_{\mathrm{n}} \mathrm{O}^{+}$, and $\mathrm{C}_{10} \mathrm{Cl}_{7-\mathrm{n}} \mathrm{H}_{\mathrm{n}} \mathrm{O}^{+}(\mathrm{n}=1$ or 2); (ii) fragments of generic formula $\mathrm{C}_{9} \mathrm{Cl}_{9-n} \mathrm{H}_{\mathrm{n}}^{+}, \mathrm{C}_{9} \mathrm{Cl}_{8-n} \mathrm{H}_{\mathrm{n}}^{+}$, $\mathrm{C}_{9} \mathrm{Cl}_{7-n} \mathrm{H}_{\mathrm{n}}^{+}, \mathrm{C}_{9} \mathrm{Cl}_{6-\mathrm{n}} \mathrm{H}_{\mathrm{n}}^{+}$, and $\mathrm{C}_{9} \mathrm{Cl}_{5-n} \mathrm{H}_{\mathrm{n}}^{+}(n=1$ or 2); (iii) fragments of generic formula $\mathrm{C}_{5} \mathrm{Cl}_{6-n} \mathrm{H}_{\mathrm{n}}^{+}, \mathrm{C}_{5} \mathrm{Cl}_{5-n} \mathrm{H}_{\mathrm{n}}^{+}$, and $\mathrm{C}_{5} \mathrm{Cl}_{4-\mathrm{n}} \mathrm{H}_{\mathrm{n}} \mathrm{O}^{+}(0 \leq \mathrm{n} \leq 2)$; (iv) fragments of formula $\mathrm{C}_{9} \mathrm{Cl}_{7} \mathrm{H}^{2+}$, $\mathrm{C}_{9} \mathrm{Cl}_{6} \mathrm{H}^{2+}$ and $\mathrm{C}_{9} \mathrm{Cl}_{5} \mathrm{H}^{2+}$ (Supplementary Figure 4 ).

Based on these fragments, identification (i.e., mono-, dior tri-hydrochlordecone) was made for metabolites $\mathrm{Ai}(1 \leq \mathrm{i}$ 


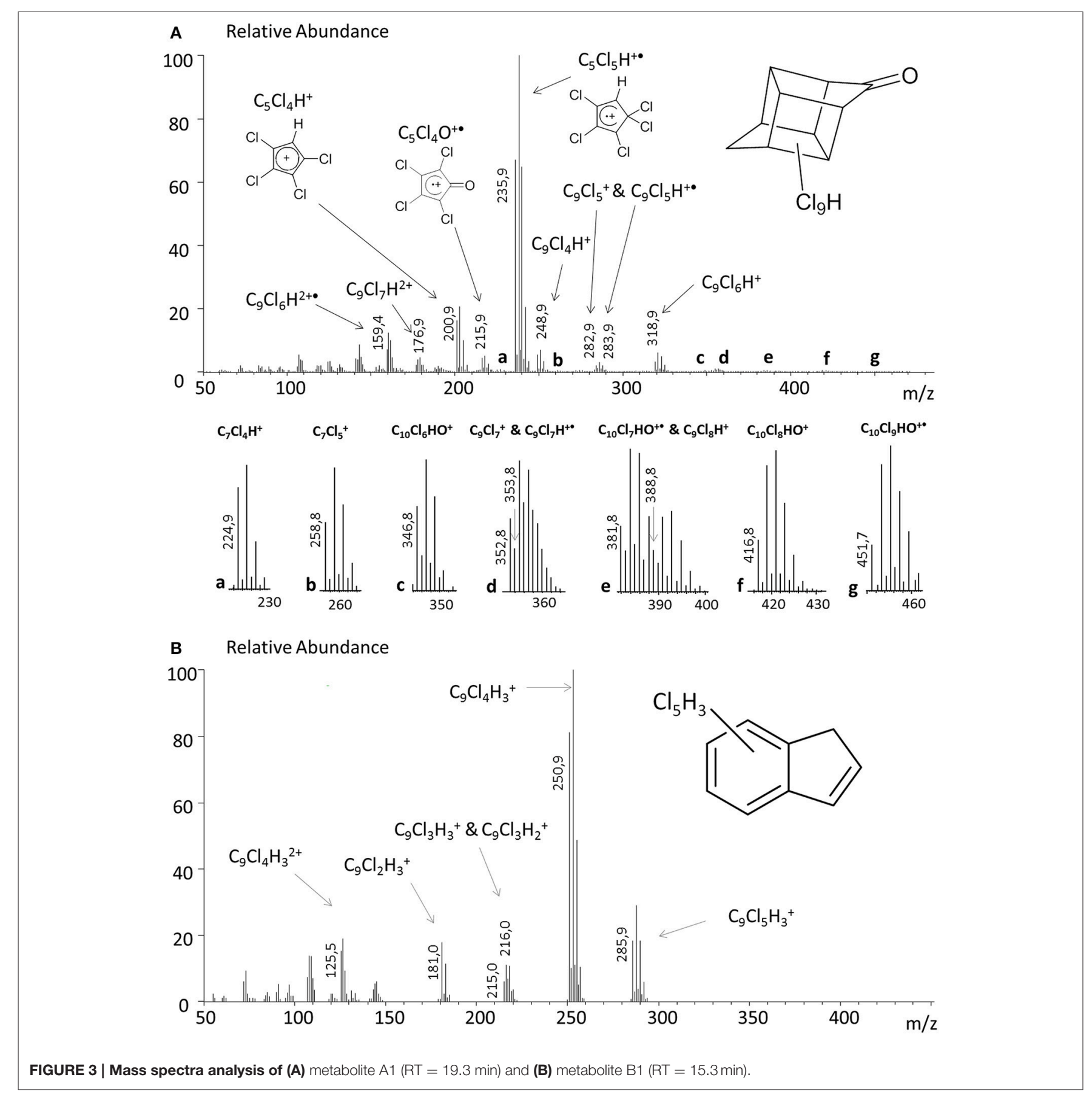

$\leq$ 11) (Table 2). Schrauzer and Katz reported in 1978 the formation of $\mathrm{C}_{9} \mathrm{Cl}_{5-n} \mathrm{H}_{n}$ compounds $(0 \leq \mathrm{n} \leq 2)$ in freecorrinoid degradation of chlordecone (Schrauzer and Katz, 1978). Based on MS and UV data, the authors assigned them as polychloroindenes (Figure 1D). Metabolites $\mathrm{Bi}(1 \leq \mathrm{i} \leq 3)$ turned out to show same type of fragments indicating a probable similar chemical structure: (i) $\mathrm{C}_{9} \mathrm{Cl}_{5} \mathrm{H}_{3}^{+}, \mathrm{C}_{9} \mathrm{Cl}_{4} \mathrm{H}_{3}^{+}$, $\mathrm{C}_{9} \mathrm{Cl}_{3} \mathrm{H}_{3}^{+}, \mathrm{C}_{9} \mathrm{Cl}_{3} \mathrm{H}_{2}^{+}$, and $\mathrm{C}_{9} \mathrm{Cl}_{2} \mathrm{H}_{3}^{+}$for metabolite $\mathrm{B1}$; (ii) $\mathrm{C}_{9} \mathrm{Cl}_{4} \mathrm{H}_{4}^{+}, \mathrm{C}_{9} \mathrm{Cl}_{3} \mathrm{H}_{4}^{+}, \mathrm{C}_{9} \mathrm{Cl}_{2} \mathrm{H}_{4}^{+}, \mathrm{C}_{9} \mathrm{Cl}_{2} \mathrm{H}_{3}^{+}$, and $\mathrm{C}_{9} \mathrm{ClH}_{4}^{+}$for metabolites B2 and B3 (Supplementary Figure 4). LC-MS analysis confirmed the proposed chemical formula for the three main metabolites produced by Citrobacter strains (Table 3). Even if neither GC-MS nor LC-MS analysis can, at that stage, quantify the ratio between $\mathrm{A} 1, \mathrm{~B} 1$ and $\mathrm{B} 3$ in the Citrobacter degradations, it is worth noticing that a loss of five and six chlorine atoms (for metabolites B1 and B3, respectively) has never been observed so far in presence of microbes nor fungi (Orndorff and Colwell, 1980; George and Claxton, 1988; Jablonski et al., 1996; Fernández-Bayo et al., 2013; Merlin et al., 2014). 


\section{(Meta)Genome Analysis}

Consortia 86 and 92 are composed of 10 and 7 scaffolds, respectively, and represent almost complete bacterial genomes (Table 1). Out of them, five are shared by the two consortia and correspond mainly to fermenter (Citrobacter sp., Dysgonomonas sp.), sulfate reducing (Desulfovibrio sp.), acetogenic (Sporomusa sp.) and a Pleomorphomonas species. The latter belongs to the order of Rhizobiales which includes among others plant endosymbionts and a large number of nitrogen fixing species. Isolated Citrobacter sp. have the highest sequence coverage, which is consistent with an important role in the two consortia. None of these species are known to be halorespiring bacteria, although a Desulfovibrio dechloracetivorans isolated from marine sediments is able to grow by coupling the oxidation of acetate to the reductive dechlorination of 2-chlorophenol (Sun et al., 2000). However any protein sequence involved in this dehalogenation has been described. Otherwise, no gene sequences related to known reductive dehalogenases (PFAM: PF13486; TIGRFAM: TIGR02486), the key enzymes in halorespiraton (Maymó-Gatell et al., 1997; Hug et al., 2013) have been found in these genomes. Interestingly, Citrobacter and Desulfovibrio spp. were previously reported to be involved in the dehalogenation of hexachlorocyclohexane isomers by a still unknown mechanism (Jagnow et al., 1977; Badea et al., 2009).

Comparisons with known bacteria were based on 16S rRNA gene sequences alignments and comparative analyses with sequenced genomes sharing a high fraction of syntenic genes.

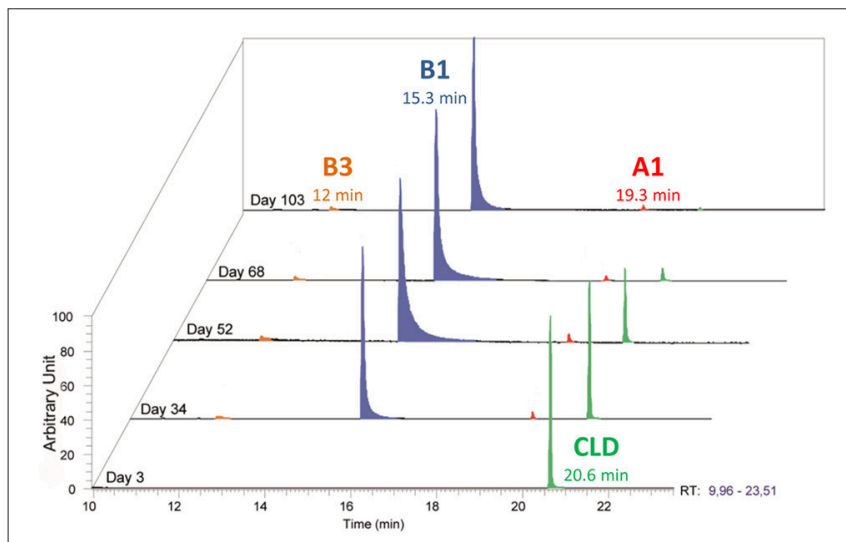

FIGURE 4 | Temporal monitoring of Citrobacter_86-1 culture by GC-MS: metabolite $\mathrm{B} 1\left(\mathrm{C}_{9} \mathrm{Cl}_{5} \mathrm{H}_{3}\right)$ in blue, metabolite $\mathrm{A} 1\left(\mathrm{C}_{10} \mathrm{Cl}_{9} \mathrm{OH}\right)$ in red, metabolite $\mathrm{B} 3\left(\mathrm{C}_{9} \mathrm{Cl}_{4} \mathrm{H}_{4}\right)$ in orange and chlordecone in green.
Two different Citrobacter species were found in consortium 86: Citrobacter_86-1 is closely related to Citrobacter amalonaticus and Citrobacter_86-2 to Citrobacter freundii (Table 1). A Desulfovibrio sp. was closely related to $D$. desulfuricans whereas the affiliation of the other Deltaproteobacterium was not clear and may represent a new genus (the 16S rRNA sequence shares only $89 \%$ identity with the closest cultivable bacterium). On the basis of its 16S rRNA gene sequence, the Sporomusa acetogenic bacterium was closely related to Sporomusa sphaeroides (not sequenced so far). The genome of this bacterium is related to the KB1 strain isolated from a trichloroethene dechlorinating consortium (Hug et al., 2012). Two Bacteroidetes belonging to the Dysgonomonas genus as well as two Alphaproteobacteria (one being close to Pleomorphomonas oryzae) are found in consortium 86. Finally, a bacterium belonging to the Clostridiales order was only found in consortium 86.

Most of the bacteria from consortium 86 appear to be facultative anaerobes, e.g., the Citrobacter genomes harbor a large number of genes involved in response to molecular oxygen (Table 1).

Since vitamin $B_{12}$ is an important compound in the reductive dehalogenation, as cofactor of reductive dehalogenases but also as protein-free corrinoid (Bommer et al., 2014; Renpenning et al., 2014; Payne et al., 2015), in both biotic (Fetzner and Lingens, 1994) and abiotic settings (Schrauzer and Katz, 1978), we searched for genes involved in the biosynthesis of this compound. Complete anaerobic pathways for vitamin $\mathrm{B}_{12}$ biosynthesis were actually identified in the genomes of Citrobacter, Desulfovibrio, Sporomusa and Pleomorphomonas detected in consortia. In addition, genes coding for vitamin $\mathrm{B}_{12}$-dependent proteins were found, such as a large number of dimethylamine and trimethylamine methyltransferases present in the Sporomusa genome, which are likely to be involved in growth on $\mathrm{N}$ methylated compounds. Citrobacter_86-1 genome possesses five vitamin $\mathrm{B}_{12}$-dependent proteins involved in different metabolic pathways (see below).

The reductive dehalogenases being iron-sulfur proteins, special interest has been focused on these proteins of unknown function and on their genomic context (Table 1).

Because no candidate genes for reductive dehalogenases were found in these consortia genomes, we searched for genes encoding other enzymes that could be involved in dehalogenation of chlordecone such as genes $\operatorname{lin} \mathrm{A}, \operatorname{lin} \mathrm{B}$ (coding respectively for a dehydrochlorinase and a haloalkane dehalogenase) and haloacid dehalogenases (van der Ploeg et al., 1991; Nagata et al., 1999). Although these genes were involved in aerobic dehalogenation, we cannot exclude that homologs

TABLE 3 | Liquid Chromatography-High Resolution Mass Spectrometry analysis of chlordecone and metabolites A1, B1, and B3.

\begin{tabular}{|c|c|c|c|c|c|}
\hline Compound & Retention time (min) & $m / z[M-H]]_{\exp }^{-}$ & $\mathrm{m} / \mathrm{z}[\mathrm{M}-\mathrm{H}]_{\mathrm{th}}^{-}$ & $\Delta(p p m)$ & Proposed neutral formula \\
\hline A1 & 10.51 & 468.72461 & 468.72559 & 2.09 & $\mathrm{C}_{10} \mathrm{Clg}_{9} \mathrm{H}_{3} \mathrm{O}_{2}$ \\
\hline B1 & 20.15 & 284.85937 & 284.85995 & 2.03 & $\mathrm{C}_{9} \mathrm{Cl}_{5} \mathrm{H}_{3}$ \\
\hline B3 & 19.05 & 250.89834 & 250.89895 & 2.43 & $\mathrm{C}_{9} \mathrm{Cl}_{4} \mathrm{H}_{4}$ \\
\hline chlordecone & 12.94 & 502.68563 & 502.68637 & 1.42 & $\mathrm{C}_{10} \mathrm{Cl}_{10} \mathrm{H}_{2} \mathrm{O}_{2}$ \\
\hline
\end{tabular}


of these proteins could act on some CLD dehalogenation steps. In summary, no evidence of proteins involved in CLD transformation has been found through analyses of genomes of consortium 86 and 92.

A special interest was for the isolated Citrobacter_86-1 and Citrobacter_92-1 which produce A1, B1 and B3 metabolites. Genomes from these two bacteria are nearly identical and are closely related to Citrobacter amalonaticus strain L8A (RefSeq assembly accession: GCF_000731055.1).

Analysis of Citrobacter_86-1 genome shed light on the anaerobic metabolism of this bacterium. Thus, genes involved in lactate, acetate, $\mathrm{CO}_{2}$ and $\mathrm{H}_{2}$ production from glucose and from pyruvate were found as well as a number of genes coding for proteins involved in anaerobic respiration (Supplementary Table 2). Among them, two DMSO reductases-like for which the substrate is unknown. The presence of a putative selenate reductase could indicate that this Citrobacter could use selenium in anaerobic respiration. Genes involved in the anaerobic glycerol utilization, including oxidative and reductive branches of fermentation were found. The vitamin $\mathrm{B}_{12}$-dependent glycerol dehydratase is the key enzyme in the reductive pathway of this fermentation. Another alcohol metabolized by Citrobacter_86-1 is the 1,2-propanediol (1,2-PD). A gene cluster involved in the degradation of 1,2-PD has been found including genes encoding 1,2-propanediol dehydratase (a vitamin $\mathrm{B}_{12}$-dependent protein) as well as shell protein of the micro compartments. Besides the ability to ferment sugars, Citrobacter_86-1 could ferment several amino acids, notably through vitamin $\mathrm{B}_{12}$-dependent glutamate mutase (glutamate fermentation), threonine and serine deaminases (threonine/serine fermentations). Finally, a gene encoding a vitamin $\mathrm{B}_{12}$ dependent methylmalonyl-CoA mutase has been found in a cluster involved in a pathway allowing the conversion of succinate to propionate in Escherichia coli, although the metabolic context of this pathway is unknown (Haller et al., 2000). Taken together these genome sequence data indicate that Citrobacter_86-1 has a versatile anaerobic metabolism and is able to use a large number of electron acceptors.

\section{CONCLUSION}

We report here the isolation and complete genome sequences of two Citrobacter bacteria as well as two consortia that mediate chlordecone transformation. Both isolated strains and consortia could be extremely useful to further investigate routes to eliminate this challenging and harmful molecule. The microbial transformation products, namely a monohydrochlordecone (A1) and two $\mathrm{C}_{9}$-compounds (B1, B3) presumably come from several dehalogenation steps, possibly coupled with

\section{REFERENCES}

Alley, E. G., Layton, B. R., and Minyard, J. P. Jr. (1974). Identification of the photoproducts of the insecticides Mirex and Kepone. J. Agric. Food Chem. 22, $442-445$.

Badea, S., Vogt, C., Weber, S., Danet, A. F., and Richnow, H. H. (2009). Stable isotope fractionation of g-hexachlorocyclohexane (lindane) elimination of the carbonyl group ( $\mathrm{C}_{9}$-metabolites). Genomes of the two isolated Citrobacter organisms, which were shown to produce these metabolites, were scrutinized in more detail for genes potentially relevant to this molecular phenotype. In the absence of convincing evidence for homologs to known reductive dehalogenases and other candidate enzymes in these Citrobacter organisms, elucidation of the degradative pathways remains elusive. MS analyses led to the identification of 14 metabolites belonging to the $\mathrm{C}_{10^{-}}$and $\mathrm{C}_{9}$-families included in a much larger metabolite library. Isolation of these compounds and their use in microbiological experiments would bring new insights into the degradation mechanisms.

To our knowledge, the present microbial degradation of chlordecone is the first one associating chlordecone disappearance and its ring-opening leading to the apparent major metabolite $\mathrm{B} 1$ of formula $\mathrm{C}_{9} \mathrm{Cl}_{5} \mathrm{H}_{3}$. The destruction of the perchlorinated bishomocubane "cage" structure presumably responsible for its environmental recalcitrance (Huggett, 1989; Macarie et al., 2016) opens the way toward its complete biomineralization.

\section{AUTHOR CONTRIBUTIONS}

Conceived and designed the experiments: SC, PS, EU, NF, JW, and DL. Analyzed the data: SC, PS, EU, VB, TB, GC, MC, NF, JW, and DL. Contributed reagents/materials/analysis: SC, PS, EU, AB, AF, VB, TB, GG, MC, LC, SF, DM, and EP. Manuscript preparation and revision: SC, PS, EU, MC, GC, NF, JW, and DL.

\section{ACKNOWLEDGMENTS}

This article is dedicated to the memory of Dr. Yves-Marie Cabidoche. Support was provided by the INRA AIP Demichlord part of PNAC I, Commissariat à l'Energie Atomique et aux Energies Alternatives (CEA), the CNRS and the University of Evry. MC work was funded by CEA. The authors would like to thank Philippe Bertin, Yves-Marie Cabidoche, Jean-Marie Côme, Stéphane Frenette, Didier Lièvremont, Fabrice MartinLaurent and Laurent Quillet for providing soils, sediments and wastewater samples. They also thank Anne Zaparucha for helpful discussions, Ekaterina Darii for LC-MS analyses and Laurence Marie for technical skills.

\section{SUPPLEMENTARY MATERIAL}

The Supplementary Material for this article can be found online at: http://journal.frontiersin.org/article/10.3389/fmicb. 2016.02025/full\#supplementary-material

during reductive dechlorination by two strains of sulfate-reducing bacteria. Environ. Sci. Technol. 43, 3155-3161. doi: 10.1021/es80 $1284 \mathrm{~m}$

Bertrand, H. F., Poly, F., Van, V. T., Lombard, N., Nalin, R., Vogel, T. M., et al. (2005). High molecular weight DNA recovery from soils prerequisite for biotechnological metagenomic library construction. J. Microbiol. Methods 62, 1-11. doi: 10.1016/j.mimet.2005.01.003 
Boetzer, M., Henkel, C. V., Jansen, H. J., Butler, D., and Pirovano, W. (2011). Scaffolding pre-assembled contigs using SSPACE. Bioinformatics 27, 578-579. doi: 10.1093/bioinformatics/btq683

Bommer, M., Kunze, C., Fesseler, J., Schubert, T., Diekert, G., and Dobbek, H. (2014). Structural basis for organohalide respiration. Science 346, 455-458. doi: $10.1126 /$ science. 1258118

Bristeau, S., Amalric, L., and Mouvet, C. (2014). Validation of chlordecone analysis for native and remediated French West Indies soils with high organic matter content. Anal. Bioanal. Chem. 406, 1073-1080. doi: 10.1007/s00216-013-7160-2

Cabidoche, Y. M., Achard, R., Cattan, P., Clermont-Dauphin, C., Massat, F., and Sansoulet, J. (2009). Long-term pollution by chlordecone of tropical volcanic soils in the French West Indies: a simple leaching model accounts for current residue. Environ. Pollut. 157, 1697-1705. doi: 10.1016/j.envpol.2008.12.015

Chouari, R., Le Paslier, D., Daegelen, P., Ginestet, P., Weissenbach, J., and Sghir, A. (2003). Molecular evidence for novel planctomycete diversity in a municipal wastewater treatment plant. Appl. Environ. Microbiol. 69, 7354-7363. doi: 10.1128/AEM.69.12.7354-7363.2003

Cordier, S., Bouquet, E., Warembourg, C., Massart, C., Rouget, F., Kadhel, P., et al. (2015). Perinatal exposure to chlordecone, thyroid hormone status and neurodevelopment in infants: the Timoun cohort study in Guadeloupe (French West Indies). Environ. Res. 138, 271-278. doi: 10.1016/j.envres.2015.02.021

Devault, D. A., Laplanche, C., Pascaline, H., Bristeau, S., Mouvet, C., and Macarie, H. (2016). Natural transformation of chlordecone into 5b-hydrochlordecone in French West Indies soils: statistical evidence for investigating long-term persistence of organic pollutants. Environ. Sci. Pollut. Res. Int. 23, 81-97. doi: $10.1007 /$ s11356-015-4865-0

Dolfing, J., Novak, I., Archelas, A., and Macarie, H. (2012). Gibbs free energy of formation of chlordecone and potential degradation products: implications for remediation strategies and environmental fate. Environ. Sci. Technol. 46, 8131-8139. doi: 10.1021/es301165p

Emeville, E., Giusti, A., Coumoul, X., Thomé, J. P., Blanchet, P., and Multigner, L. (2015). Associations of plasma concentrations of dichlorodiphenyldichloroethylene and polychlorinated biphenyls with prostate cancer: a case-control study in Guadeloupe (French West Indies). Environ. Health Perspect. 123, 317-323. doi: 10.1289/ehp.1408407

Epstein, S. S. (1978). Kepone hazard evaluation. Sci. Total Environ. 9, 1-62.

Fariss, M. W., Blanke, R. V., Saady, J. J., and Guzelian, P. S. (1980). Demonstration of major metabolic pathways for chlordecone (kepone) in humans. Drug Metab. Dispos. 8, 434-438.

Fernández-Bayo, J. D., Saison, C., Voltz, M., Disko, U., Hofmann, D., and Berns, A. E. (2013). Chlordecone fate and mineralisation in a tropical soil (andosol) microcosm under aerobic conditions. Sci. Total Environ. 463-464, 395-403. doi: 10.1016/j.scitotenv.2013.06.044.

Fetzner, S., and Lingens, F. (1994). Bacterial dehalogenases: biochemistry, genetics, and biotechnological applications. Microbiol. Rev. 58, 641-685.

Fritz, M. (2009). Lautorisation du Chlordécone en France 1968-1981, Rapport AFSSET. Available online at: http://www.observatoire-pesticides.fr/upload/ bibliotheque/457291400429630296486151015810/autorisation_chlordecone_ france_1968_1981.pdf

George, S. E., and Claxton, L. D. (1988). Biotransformation of chlordecone by Pseudomonas species. Xenobiotica 18, 407-416. doi: 10.3109/00498258809041677

Gilbert, E. E., Lombardo, P., Rumanovski, E. J., and Walker, G. L. (1966). Preparation and insecticidal evaluation of alcoholic analogs of kepone. J. Agric. Food Chem. 14, 111-114. doi: 10.1021/jf60144a004

Gkanogiannis, A., Gazut, S., Salanoubat, M., Kanj, S., and Brüls, T. (2016). A scalable assembly-free variable selection algorithm for biomarker discovery from metagenomes. BMC Bioinformatics 17:311. doi: 10.1186/s12859-016-1186-3

Haller, T., Buckel, T., Rétey, J., and Gerlt, J. A. (2000). Discovering new enzymes and metabolic pathways: conversion of succinate to propionate by Escherichia coli. Biochemistry 39, 4622-4629. doi: 10.1021/bi992888d

Harless, R. L., Harris, D. E., Sovocool, G. W., Zehr, R. D., Wilson, N. K., and Oswald, E. O. (1978). Mass spectrometric analyses and characterization of kepone in environmental and human samples. Biomed. Mass Spectrom. 5, 232-237. doi: 10.1002/bms.1200050312

Houston, T. E., Mutter, L. C., Blanke, R. V., and Guzelian, P. S. (1981). Chlordecone alcohol formation in the Mongolian gerbil (Meriones Unguiculatus): a model for human metabolism of chlordecone (kepone). Fundam. Appl. Toxicol. 1, 293-298.

Hug, L. A., Beiko, R. G., Rowe, A. R., Richardson, R. E., and Edwards, E. A. (2012). Comparative metagenomics of three Dehalococcoides-containing enrichment cultures: the role of the non-dechlorinating community. BMC Genomics 13:327. doi: 10.1186/1471-2164-13-327

Hug, L. A., Maphosa, F., Leys, D., Löffler, F. E., Smidt, H., Edwards, E. A., et al. (2013). Overview of organohalide-respiring bacteria and a proposal for a classification system for reductive dehalogenases. Philos. Trans. R. Soc. Lond. B Biol. Sci. 368:20120322. doi: 10.1098/rstb.2012.0322

Huggett, R. J. (1989). "Kepone and the James river," in Contaminated Marine Sediments: Assessments and Remediation, U.S. Environmental Protection Agency (EPA) and Food and Drug Administration (FDA) (Washington, DC: National Academic Press), 417-424.

Jablonski, P. E., Pheasant, D. J., and Ferry, J. G. (1996). Conversion of kepone by Methanosarcina thermophila. FEMS Microbiol. Lett. 139, 169-176.

Jagnow, G., Haider, K., and Ellwardt, P. C. (1977). Anaerobic dechlorination and degradation of hexachlorocyclohexane isomers by anaerobic and facultative anaerobic bacteria. Arch. Microbiol. 115, 285-292.

Joly, P. B. (2010). La saga du chlordécone aux Antilles françaises. Reconstruction Chronologique 1968-2008. Rapport INRA Sens. Available online at: http://www.observatoire-pesticides.fr/upload/bibliotheque/8521735307832222 42256849728077/saga_chlordecone_antilles_francaises_1968_2008.pdf (in French).

Le Déault, J. Y., and Procaccia, C. (2009). Les Impacts de l'utilisation de la Chlordécone et des Pesticides aux Antilles: Bilan et Perspectives d'évolution. Report no. 1778 of French National Assembly (in French).

Löffler, F. E., Sanford, R. A., and Tiedje, J. M. (1996). Initial characterization of a reductive dehalogenase from Desulfitobacterium chlororespirans Co23. Appl. Environ. Microbiol. 62, 3809-3813.

Macarie, H., Novak, I., Sastre-Conde, I., Labrousse, Y., Archelas, A., and Dolfing, J. (2016). "Theoretical approach of chlordecone biodegradation," in Crisis Management of Chronic Pollution: Contaminated Soil and Human Health, eds M. Jannoyer, P. Cattan, T. Woignier, and F. Clostre (Boca Raton, FL: CRC Press), 191-209.

Martin-Laurent, F., Sahnoun, M., Merlin, C., Vollmer, G., and Lübke, M. (2014). Detection and quantification of chlordecone in contaminated soils from the French West Indies by GC-MS using the ${ }^{13} \mathrm{C} 10$-chlordecone stable isotope as a tracer. Environ. Sci. Pollut. Res. Int. 21, 4928-4933. doi: 10.1007/s11356-013-1839-y

Matolcsy, C., Nadasy, M., and Andriska, V. (1988). Pesticide chemistry. Stud. Environn. Sci. 32, 1-809.

Maymó-Gatell, X., Chien, Y., Gossett, J. M., and Zinder, S. H. (1997). Isolation of a bacterium that reductively dechlorinates tetrachloroethene to ethene. Science 276, 1568-1571.

Merlin, C., Devers, M., Crouzet, O., Heraud, C., Steinberg, C., Mougin, C., et al. (2014). Characterization of chlordecone-tolerant fungal populations isolated from long-term polluted tropical volcanic soil in the French West Indies. Environ. Sci. Pollut. Res. Int. 21, 4914-4927. doi: 10.1007/s11356-013-1971-8

Mouvet, C., Dictor, M. C., Bristeau, S., Breeze, D., and Mercier, A. (2016). Remediation by chemical reduction in laboratory mesocosms of three chlordecone-contaminated tropical soils. Environ. Sci. Pollut. Res. Int. doi: 10.1007/s11356-016-7582-4. [Epub ahead of print].

Multigner, L., Ndong, J. R., Giusti, A., Romana, M., and Delacroix-Maillard, H. (2010). Chlordecone exposure and risk of prostate cancer. J. Clin. Oncol. 28, 3457-3462. doi: 10.1200/JCO.2009.27.2153

Multigner, L., Kadhel, P., Rouget, F., Blanchet, P., and Cordier, S. (2016). Chlordecone exposure and adverse effects in French West Indies populations. Environ. Sci. Pollut. Res. Int. 23, 3-8. doi: 10.1007/s11356-015-4621-5

Nagata, Y., Futamura, A., Miyauchi, K., and Takagi, M. (1999). Two different types of dehalogenases, LinA and LinB, involved in gamma-hexachlorocyclohexane degradation in Sphingomonas paucimobilis UT26 are localized in the periplasmic space without molecular processing. J. Bacteriol. 181, 5409-5413.

Orndorff, S. A., and Colwell, R. R. (1980). Microbial transformation of kepone. Appl. Environ. Microbiol. 39, 398-406.

Payne, K. A., Quezada, C. P., Fisher, K., Dunstan, M. S., Collins, F. A., Sjuts, H., et al. (2015). Reductive dehalogenase structure suggests a mechanism for $\mathrm{B}_{12}$-dependent dehalogenation. Nature 517, 513-516. doi: 10.1038/nature13901 
Renpenning, J. S., Keller, S. S., Cretnik, S. O., Shouakar-Stash, O. M., Elsner, M. T., Schubert, T. et al. (2014). Combined C and $\mathrm{Cl}$ isotope effects indicate differences between corrinoids and enzyme (Sulfurospirillum Multivorans $P(e a)$ in reductive dehalogenation of tetrachloroethene, but not trichloroethene. Environ. Sci. Technol. 48, 11837-11845. doi: 10.1021/es50 $3306 \mathrm{~g}$

Riviere, D., Desvignes, V., Pelletier, E., Chaussonnerie, S., Guermazi, S., Weissenbach, J., et al. (2009). Towards the definition of a core of microorganisms involved in anaerobic digestion of sludge. ISME J. 3, 700-714. doi: 10.1038 /ismej.2009.2

Schrauzer, G. N., and Katz, R. N. (1978). Reductive dechlorination and degradation of mirex and kepone with vitamin $\mathrm{B}_{12}$. Bioinorg. Chem. 9, 23-143.

Soine, P. J., Blanke, R. V., and Schwartz, C. C. (1983). Chlordecone metabolism in the pig. Toxicol. Lett. 17, 35-41.

Sun, B., Cole, J. R., Sanford, R. A., and Tiedje, J. M. (2000). Isolation and characterization of Desulfovibrio dechloracetivorans Sp. Nov., a marine dechlorinating bacterium growing by coupling the oxidation of acetate to the reductive dechlorination of 2-chlorophenol. Appl. Environ. Microbiol. 66, 2413. doi: 10.1128/AEM.66.6.2408-2413.2000

Uk, S., Himel, C. M., and Dirks, T. F. (1972). Mass spectral pattern of Mirex (dodecachlorooctahydro-1,3,4-metheno-2H-cyclobuta (cd) pentalene) and of Kepone (decachlorooctahydro-1,3,4-metheno-2H-cyclobuta (cd)-pentalen-2one) and its application in residue analysis. Bull. Environ. Contam. Toxicol. 7, 207-215.

UNEP/POPS/POPRC.1/INF/6 (2005). United Nations Environment Programme, Stockholm Convention on Persistent Organic Pollutants. Persistent Organic Pollutants Review Committee, Consideration of chemicals proposed for inclusion in Annexes $A, B$, and $C$ of the Convention: Chlordecone.
Available onilne at: http://www.pops.int/\%5C/documents/meetings/poprc/ meeting_docs/en/POPRC1-INF6-w-anx.pdf

UNEP/POPS/POPRC.3/10 (2007). Projet d'évaluation de la Gestion des Risques: Chlordécone. Available online at: http://www.pops.int/documents/meetings/ poprc_3/meetingdocs/poprc3_doc/10/K0762894.F_POPS_POPRC_3_10.pdf

Vallenet, D., Belda, E., Calteau, A., Cruveiller, S., Engelen, S., Lajus, A., et al. (2013). MicroScope-an integrated microbial resource for the curation and comparative analysis of genomic and metabolic data. Nucleic Acids Res. 41, D636-D647. doi: $10.1093 /$ nar/gks1194

van der Ploeg, J., van Hall, G., and Janssen, D. B. (1991). Characterization of the haloacid dehalogenase from Xanthobacter autotrophicus GJ10 and sequencing of the dhlB gene. J. Bacteriol. 173, 7925-7933.

Wilson, N. K., and Zehr, R. D. (1979). Structures of some kepone photoproducts and related chlorinated pentacyclodecanes by $\mathrm{C}-13$ and proton nuclear magnetic resonance. J. Org. Chem. 44, 1278-1282.

Conflict of Interest Statement: The authors declare that the research was conducted in the absence of any commercial or financial relationships that could be construed as a potential conflict of interest.

Copyright () 2016 Chaussonnerie, Saaidi, Ugarte, Barbance, Fossey, Barbe, Gyapay, Brüls, Chevallier, Couturat, Fouteau, Muselet, Pateau, Cohen, Fonknechten, Weissenbach and Le Paslier. This is an open-access article distributed under the terms of the Creative Commons Attribution License (CC BY). The use, distribution or reproduction in other forums is permitted, provided the original author (s) or licensor are credited and that the original publication in this journal is cited, in accordance with accepted academic practice. No use, distribution or reproduction is permitted which does not comply with these terms. 